\title{
Acculturation, socioeconomic status, obesity and lifestyle factors among low-income Puerto Rican women in Connecticut, U.S., 1998-1999
}

\author{
Nurgül Fitzgerald, ${ }^{1}$ David Himmelgreen, ${ }^{2}$ Grace Damio, ${ }^{3}$ Sofia Segura-Pérez, ${ }^{4}$ \\ Yu-Kuei Peng, ${ }^{5}$ and Rafael Pérez-Escamilla ${ }^{6}$
}

Suggested citation

Fitzgerald N, Himmelgreen D, Damio G, Segura-Pérez S, Peng Y-K, Pérez-Escamilla R. Acculturation, socioeconomic status, obesity and lifestyle factors among low-income Puerto Rican women in Connecticut, U.S., 1998-1999. Rev Panam Salud Publica. 2006;19(5):306-13.

ABSTRACT Objectives. To examine the associations of socioeconomic status and acculturation with obesity and lifestyle characteristics that may be risk factors for diabetes and cardiovascular disease among low-income Puerto Rican women.

Methods. This cross-sectional study was conducted between 1998 and 1999 by interviewing a convenience sample of 200 low-income Puerto Rican female caretakers of young children in Hartford, Connecticut, United States of America. Various recruitment methods were used to ensure adequate representation of the target community. The associations of obesity (body mass index $\geq 30.0$ ) and lifestyle factors (physical activity, cigarette smoking, alcohol consumption, food intake) with socioeconomic status (education, employment, car ownership), acculturation, age, and marital status were examined with Spearman rho, chi-squared, and Mann-Whitney $U$ tests and logistic regression analyses.

Results. Mean age was 29 years. Obesity (40\%), physical inactivity (47\%), and cigarette smoking (32\%) were common. Less acculturated participants were $57 \%$ less likely to smoke and $54 \%$ less likely to be obese than their more acculturated counterparts. Lower socioeconomic status (not finishing high school or not owning a car) was associated with a higher likelihood of obesity, but unemployed (vs. employed) women were less likely to be obese ( $\mathrm{P}<0.05)$. Women who did not own a car consumed meat, eggs and fish less often than those who owned a car. Smokers were more likely to have an unhealthy food intake pattern than nonsmokers.

Conclusions. The associations of acculturation and socioeconomic status with some lifestyle characteristics suggest the need for culturally appropriate programs to promote healthy lifestyle behaviors in this low-income community.

Key words Acculturation, cardiovascular diseases, diabetes mellitus, Hispanic Americans, obesity, physical activity, socioeconomic status, women.

\begin{abstract}
Department of Family and Community Health Sciences, Department of Nutritional Sciences, Rutgers, the State University of New Jersey, New Brunswick, New Jersey, United States of America. Send correspondence and reprint requests to: Nurgül Fitzgerald, Department of Nutritional Sciences, Rutgers, the State University of New Jersey, 26 Nichol Ave., New Brunswick, NJ 08901, United States of
\end{abstract}

America; telephone: (732) 932-3835; fax: (732) 9326522; e-mail: nfitzgerald@rcre.rutgers. edu

2 Department of Anthropology, University of South Florida, Tampa, Florida, United States of America.

3 Center for Community Nutrition, Center for Women and Children's Health, Hispanic Health Council, Hartford, Connecticut, United States of America.
Hispanic Health Council, Hartford, Connecticut, United States of America.

Connecticut Department of Public Health, Hartford, Connecticut, United States of America.

6 Connecticut Latino Health Disparities NIH EXPORT Center and Department of Nutritional Sciences, University of Connecticut, Storrs, Connecticut, United States of America. 
Several modifiable factors such as obesity, physical inactivity, poor diet and cigarette smoking (1) are related to an increased risk of type 2 diabetes, and light to moderate alcohol intake may be protective against this disease (2). These lifestyle factors are reported to have similar associations with cardiovascular disease (CVD) (3-5), and they may also vary according to socioeconomic status (SES) and acculturation. Physical activity (6), alcohol intake (7) and cigarette smoking have been reported to increase with acculturation and decrease with higher SES $(8,9)$ among Mexican Americans. Body mass index (BMI) $(10,11)$, food intakes $(12,13)$ and the incidence of type 2 diabetes (10) also vary depending on acculturation or SES levels.

Hispanics, the largest minority group in the United States of America, have higher rates of overweight and of physical inactivity during leisure time (14), and they are about twice as likely to have diabetes (15) compared to nonHispanic whites. Most research involving type 2 diabetes and CVD risk factors among Hispanics in the United States has been conducted among Mexican Americans, although differences may exist between subgroups of Hispanics. For instance, Puerto Ricans have higher rates of diabetes (16) and cigarette smoking (17) but slightly lower rates of overweight (18) than Mexican Americans. Despite their relatively higher educational levels, Puerto Rican households are more likely to have unemployed persons and belowpoverty conditions $(14,19)$ than Mexican American households. Research that has examined risk factors for diabetes and CVD among various Hispanic populations in the United States is scarce but ultimately necessary to overcome health disparities.

The Acculturation and Nutrition Needs Assessment (ANNA) project was conducted among low-income Puerto Rican preschool-age children and their caretakers in Hartford, Connecticut, United States to determine the nutrition-related intervention needs of this community. The objective of the analyses presented here was to exam- ine the relationships of acculturation and SES with lifestyle-related factorsobesity, physical inactivity, smoking, alcohol intake and dietary patternsthat may be associated with the risk of diabetes or CVD among Puerto Rican caretakers. We hypothesized that being highly acculturated, as assessed by English language preference and proficiency, would be associated with higher rates of physical activity but also higher rates of obesity, smoking, consuming alcohol, and poor diet. We also hypothesized that low SES would be related to a poorer disease risk factor profile.

\section{MATERIALS AND METHODS}

\section{Survey methods and population}

The ANNA project was conducted with a convenience sample of 201 lowincome Puerto Rican residents of Hartford, Connecticut (United States) between May 1998 and September 1999. The current analysis included 200 women aged 15 to 62 years; the exclusion of one man did not influence the results. Selection criteria included Puerto Rican self-identification, residing in Hartford, eligibility to receive food stamps, and being a non-pregnant primary caretaker of at least one preschool-age child. Pregnant women were not included in the study because of potential changes in their food intake and lifestyle behaviors.

To ensure that our sample of interviewees accurately represented the study population, participants were recruited through various locations and services such as healthcare and community nutrition services provided by the Hispanic Health Council $(43.0 \%)$, the Special Supplemental Nutrition Program for Women, Infant, and Children, Connecticut Children's Medical Center, and health fairs $(41.5 \%)$, schools $(1.5 \%)$, and street outreach or word of mouth $(14.0 \%)$. The study was approved by the Human Subjects Review Committees of the University of Connecticut and the Hispanic Health Council. Participants signed an informed consent form prior to the interview, and at the end of the interview they received nutrition education materials and a small monetary incentive.

Interviews were conducted by trained bilingual interviewers in the language of the participant's choice (9.0\% in English, $77.0 \%$ in Spanish, $14.0 \%$ in both languages) either at the participant's home $(90.5 \%)$ or at the Hispanic Health Council center (9.5\%). We did not detect any significant differences in SES or in demographic or lifestyle characteristics according to interview location. The questionnaire was based on studies previously conducted in this community (20), and it was extensively pretested for face and content validity, including testing with 13 Hispanic Health Council staff members and their families, and an ethnographic application in 22 households (21). Height and weight were measured by interviewers according to standard procedures (22). BMI $\left(\mathrm{kg} / \mathrm{m}^{2}\right)$ was categorized as underweight (<18.5), normal (18.5-24.9), overweight (25.0-29.9) and obese ( $\geq 30.0$ ) (23). Participants were considered to be physically active if they answered "Yes" to the question, "Do you exercise at least three times a week for half an hour each time?" This definition was inclusive of all exercise types and was adapted from recommendations (24) available at the time of the study. Alcohol use and cigarette smoking (yes or no) were reported for current use regardless of the amount consumed.

Primary language spoken at home and self-assessed English proficiency were used as indicators of acculturation status. On the basis of the bivariate associations of these two variables with diabetes or CVD risk factors, we categorized acculturation status as low (speaks Spanish only or not fluent in English) or high (speaks English only or both languages, and fluent in English). Preferred language was found to be as reliable as a more comprehensive scale (21), and it is widely used as a valid proxy for acculturation $(11,25,26)$.

Employment (employed or unemployed at the time of the inter- 
view) and education (no high school diploma, or high school diploma or higher) were used as SES indicators. Having a car (yes or no) was included as an additional variable to provide further insight into economic status, because unemployment and low education were expected to be common in this sample. Car ownership has been used by others as a valid indicator of material deprivation or SES (27-29). Marital status was classified as married (married or common-law) and not married (single, divorced, widowed, or separated).

Food intake patterns were examined with a 14-item food frequency questionnaire, which was shown to be reliable in the target community in comparison to a more comprehensive questionnaire (30). Based on the general dietary guidelines as outlined in the MyPyramid assessment tool (31), food items were classified into five groups: grains (pasta, bread, rice, cereal), meats (meat, fish, shellfish, and eggs), dairy products (milk, cheese, yogurt), fruits/vegetables/legumes (fruits, fruit juices, green leafy, starchy, and other vegetables, legumes), and discretionary foods (soft and artificially flavored drinks, salty/high fat/high sugar snacks, and sweets/ desserts). According to MyPyramid, legumes can be grouped with meats or vegetables; placing legumes in the meat group did not change any of our results.

\section{Statistical analyses}

Bivariate analyses were conducted with chi-squared, Spearman rho and Mann-Whitney U tests with the SPSS v. 12.0 for Windows (SPSS Inc., Chicago, IL, U.S.). Multivariate analyses were conducted with logistic regression. The outcome variables were obesity (BMI $\geq 30.0$ ), physical activity, cigarette smoking and alcohol consumption. The independent variables were acculturation level, SES (employment, education and car ownership), age and marital status; the intakes of five food groups were entered as co- variates. The associations of acculturation and SES (as independent variables) with food group intakes (as dependent variables) were also examined. Because excluding participants with self-reported diabetes $(n=10)$ did not result in any substantial change in the final multivariate models, these participants were included in the analyses. A two-tailed $P$ value of less than 0.05 or a $95 \%$ confidence interval (CI) of the odds ratio (OR) that excluded the value of 1.0 were considered statistically significant. To report the results, percentages for lower or higher likelihood of a given outcome were calculated as the difference between the OR and 1.00 (value of nondifference). For example, 1.00-0.43 = 0.57 , i.e., a $57 \%$ lower likelihood for the outcome. The goodness of fit of the models was examined with the Hosmer-Lemeshow test and considered adequate at $P=0.05$ or greater. Multicollinearity was examined with a tolerance level of less than 0.20 .

\section{RESULTS}

This was a relatively young (average age $=29$ years), low-SES population, as indicated by the low employment rate $(23.5 \%)$, educational level $(38 \%$ high school graduate or higher) and car ownership rate (41.5\%) (Table 1). About $26 \%$ of the participants were highly acculturated. About 53\% reported exercising regularly, but $40 \%$ were obese. Almost one third of all participants were current cigarette smokers, and a smaller percentage $(16.5 \%)$ reported current alcohol consumption.

\section{Food intake patterns}

Although participants reported consuming fruits, vegetables, and legumes about 4.5 times per day, fruit juice accounted for almost half of this frequency (Table 1). Dairy products were consumed less than twice per day. On average, study participants consumed discretionary foods 2.6 times per day, with soft drinks accounting for most of this frequency (61\%).

Acculturation was not significantly related to any of the food group intakes in the bivariate analysis. There was a positive correlation between educational level and fruit, vegetable and legume intake $(r=0.148, P=0.036)$, and an inverse correlation between age and discretionary food intake ( $r=-0.201, P=0.004)$, but education and age did not explain substantial proportions of the variance in food intakes after adjustment for likely confounders. However, participants without a car were $57 \%$ less likely to consume foods in the meat group above the median value (1.4 times/day) compared to their counterparts who had a car (OR $0.43,95 \%$ CI $0.23-0.82$, $P=0.01$ ) after adjustment for acculturation, age, other SES variables, BMI, physical activity, cigarette smoking and alcohol intake.

\section{Obesity}

Multivariate correlates of obesity, physical activity, cigarette smoking, and alcohol consumption are shown in Table 2. Less acculturated women were $54 \%$ less likely to be obese than their highly acculturated counterparts after adjustment for lifestyle factors and SES. Unemployment (vs. employment) was associated with a 65\% lower likelihood of being obese, but other indicators of low SES (i.e., lower educational level or not owning a car) were related to a higher likelihood of obesity. Obese participants were likely to consume meat, eggs, and fish less frequently than their counterparts with lower BMI.

\section{Physical activity}

Although acculturation tended to show a positive association with physical activity $(P=0.101)$, low SES was not significantly related to physical activity, and adjustment for smoking, alcohol intake, and BMI did not alter the associations. Physically active 
TABLE 1. Characteristics of low-income Puerto Rican women in Connecticut, 1998-1999

\begin{tabular}{|c|c|c|}
\hline & No. ${ }^{a}$ & Mean \pm SD or $\%$ \\
\hline Age, years & 200 & $28.7 \pm 9.7$ \\
\hline Education: Some high school or less & 124 & 62.0 \\
\hline Has a car & 83 & 41.5 \\
\hline Employed & 47 & 23.5 \\
\hline Currently receives food stamps & 155 & 77.5 \\
\hline Married/common law & 79 & 39.5 \\
\hline Single, no partner & 98 & 49.0 \\
\hline Separated/divorced/widowed & 23 & 11.5 \\
\hline Number of years in the United States & 200 & $16.1 \pm 10.8$ \\
\hline Low acculturation ${ }^{b}$ & 148 & 74.0 \\
\hline High acculturation & 52 & 26.0 \\
\hline Exercises regularly (at least 3 times/week, 0.5 hours each time) & 106 & 53.0 \\
\hline Consumes alcohol & 33 & 16.5 \\
\hline Number of drinks consumed/week & 32 & $3.0 \pm 3.9$ \\
\hline Smokes cigarettes & 64 & 32.0 \\
\hline Number of cigarettes smoked/day & 63 & $10.2 \pm 8.9$ \\
\hline Body mass index & 196 & $29.0 \pm 7.0$ \\
\hline Underweight & 7 & 23.6 \\
\hline Normal & 51 & 26.0 \\
\hline Overweight & 60 & 30.6 \\
\hline Obese & 78 & 39.8 \\
\hline Has self-reported diabetes & 10 & 5.0 \\
\hline Grain (bread, pasta, rice, cereal) intake, frequency/day & 200 & $1.2 \pm 0.8$ \\
\hline Fruit, vegetable, legume intake, frequency/day & 200 & $4.5 \pm 2.4$ \\
\hline Fruits & 200 & $0.9 \pm 0.9$ \\
\hline Fruit juices & 200 & $2.2 \pm 1.6$ \\
\hline Vegetables & 200 & $0.9 \pm 0.8$ \\
\hline Legumes & 200 & $0.6 \pm 0.4$ \\
\hline Meat, egg, fish intake, frequency/day & 199 & $1.5 \pm 0.9$ \\
\hline Meats & 199 & $1.0 \pm 0.6$ \\
\hline Eggs & 199 & $0.4 \pm 0.5$ \\
\hline Fish & 199 & $0.1 \pm 0.1$ \\
\hline Dairy product intake, frequency/day & 200 & $1.4 \pm 1.2$ \\
\hline Soda, snack, sweets intake, frequency/day & 200 & $2.6 \pm 2.5$ \\
\hline Soft drinks & 200 & $1.6 \pm 1.9$ \\
\hline Snacks & 200 & $0.4 \pm 0.5$ \\
\hline Sweets and desserts & 200 & $0.6 \pm 0.8$ \\
\hline
\end{tabular}

women were likely to consume dairy products more often than their less active counterparts.

\section{Cigarette smoking}

Acculturation $(P<0.01)$ and alcohol consumption $(P<0.001)$ were positively related to cigarette smoking after adjustment for other confounders. Women were more than twice as likely to smoke cigarettes if they were not married (vs. married). Inter- estingly, smokers appeared to consume fruits, vegetables and legumes less often, and sodas, snacks, and sweets more often, than nonsmokers. Further adjustment (data not shown) for car ownership, BMI, and physical activity did not attenuate these associations.

\section{Alcohol intake}

Being employed was significantly related to alcohol consumption. Among the food groups, grains were likely to be consumed less often by drinkers than by nondrinkers. Adjusting for car ownership, BMI, and physical activity did not attenuate the associations in the final model.

\section{DISCUSSION}

These analyses documented significant associations between acculturation, SES and lifestyle characteristics that can act as risk factors for type 2 diabetes or 
TABLE 2. Multivariate correlates of obesity, physical activity, cigarette smoking, and alcohol consumption among low-income Puerto Rican women in Connecticut, 1998-1999

\begin{tabular}{|c|c|c|c|c|}
\hline Multivariate correlates ${ }^{a}$ & $\begin{array}{c}\text { Obesity }^{\mathrm{b}} \\
\text { OR }(95 \% \mathrm{Cl}) \\
\text { No. }=195^{f}\end{array}$ & $\begin{array}{c}\text { Physical } \\
\text { activityc } \\
\text { OR }(95 \% \mathrm{Cl}) \\
\text { No. }=200\end{array}$ & $\begin{array}{c}\text { Cigarette } \\
\text { smoking }^{\mathrm{d}} \\
\text { OR }(95 \% \mathrm{Cl}) \\
\text { No. }=200\end{array}$ & $\begin{array}{c}\text { Alcohol } \\
\text { intake }\end{array}$ \\
\hline Low acculturation & $0.46(0.21-0.97)^{\mathrm{g}}$ & $0.55(0.27-1.13)$ & $0.19(0.09-0.42)^{\mathrm{h}}$ & $1.43(0.55-3.75)$ \\
\hline High acculturation & 1.00 & 1.00 & 1.00 & 1.00 \\
\hline$<$ High school diploma & $3.00(1.48-6.09)^{\prime}$ & $0.72(0.39-1.35)$ & $1.10(0.53-2.30)$ & $0.71(0.30-1.70)$ \\
\hline$\geq$ High school graduate & 1.00 & 1.00 & 1.00 & 1.00 \\
\hline Not married & $0.53(0.27-1.03)$ & $0.80(0.43-1.50)$ & $2.06(0.99-4.25)^{g}$ & $1.10(0.46-2.61)$ \\
\hline Married/common law & 1.00 & 1.00 & 1.00 & 1.00 \\
\hline Unemployed & $0.35(0.15-0.80)^{\prime}$ & $0.55(0.26-1.16)$ & $1.53(0.63-3.69)$ & $0.23(0.09-0.57)^{i}$ \\
\hline Employed & 1.00 & 1.00 & 1.00 & 1.00 \\
\hline Does not have a car & $2.12(1.04-4.31)^{g}$ & $1.00(0.53-1.89)$ & $\ldots$ & $\ldots$ \\
\hline Has a car & 1.00 & 1.00 & & \\
\hline Age & $1.03(0.99-1.06)$ & $0.98(0.95-1.01)$ & $1.04(1.00-1.08)^{\mathrm{g}}$ & $0.96(0.92-1.01)$ \\
\hline \multicolumn{4}{|l|}{ Does not consume } & NA \\
\hline Consumes alcohol & 1.00 & 1.00 & & \\
\hline Nonsmoker & $1.49(0.71-3.11)$ & $1.04(0.53-2.04)$ & NA & $0.26(0.11-0.63)^{i}$ \\
\hline Smoker & 1.00 & 1.00 & & 1.00 \\
\hline Physically inactive & $1.39(0.73-2.66)$ & NA & $\cdots$ & $\ldots$ \\
\hline Physically active & 1.00 & & & \\
\hline $\begin{array}{l}\text { Fruit/vegetable/legume } \\
\text { intake } \\
\text { Grain/cereal/pasta }\end{array}$ & $\cdots$ & $\cdots$ & $0.83(0.71-0.96)^{i}$ & $\cdots$ \\
\hline intake & & $\cdots$ & $\cdots$ & $0.48(0.28-0.83)^{\mathrm{i}}$ \\
\hline Meat/egg/fish intake & $0.60(0.36-0.99)^{9}$ & $\ldots$ & $\ldots$ & $\ldots$ \\
\hline Dairy product intake & $\ldots$ & $1.57(1.20-2.06)^{\mathrm{h}}$ & $\ldots$ & $\ldots$ \\
\hline \multicolumn{5}{|l|}{ Soda/snack/sweets } \\
\hline intake & $\cdots$ & $\cdots$ & $1.32(1.13-1.54)^{\mathrm{h}}$ & $\cdots$ \\
\hline \multicolumn{5}{|c|}{$\begin{array}{l}\text { a Logistic regression analyses. Obesity (BMI } \geq 30) \text {; physically active (exercise at least three times a week, } 0.5 \text { hours each time); current cigarette smoking (yes } / \mathrm{no}) \text {; } \\
\text { current alcohol intake (yes/no); acculturation determined by English proficiency and primary language spoken at home; food intakes (frequency per day), age } \\
\text { (years). Odds ratios for age, and food intake frequencies are indicated for } 1 \text {-unit change in the independent variable. Cl, confidence interval; OR, odds ratio; NA, } \\
\text { not applicable; Other variables }(. . .) \text { were not included in the model due to theoretical reasons or because they did not contribute significantly to the model. } \\
\text { b Hosmer-Lemeshow } \chi^{2}=6.951, \mathrm{df}=8, P=0.542 ; \text { classification } \% \text { correct }=66.7 \text {. } \\
\text { c Hosmer-Lemeshow } \chi^{2}=9.194, \mathrm{df}=8, P=0.326 ; \text { classification \% correct }=62.0 \text {. } \\
\text { d Hosmer-Lemeshow } \chi^{2}=8.251, \mathrm{df}=8, P=0.409 ; \text { classification } \% \text { correct }=73.5 \text {. } \\
\text { e Hosmer-Lemeshow } \chi^{2}=6.114, \mathrm{df}=8, P=0.634 ; \text { classification \% correct }=84.0 \text {. } \\
\text { f Total number is less than } 200 \text { because of missing data. } \\
\text { g } P<0.05 \text {. } \\
\text { h } P<0.001 \text {. } \\
\text { i } P<0.01 \text {. }\end{array}$} \\
\hline
\end{tabular}

CVD among low-income Puerto Rican women in Hartford, Connecticut.

\section{Obesity}

We found a positive association between obesity and acculturation. Several other studies support a positive (11, 32-34) or a nonlinear relationshippeople at the low and high ends of acculturation having a lower BMI than those in the middle categories-among predominantly Mexican American populations (35). In one of the few published studies of Puerto Rican women, Khan et al. (11) detected no significant association between obesity and acculturation as measured by language use. However, in a subgroup of the ANNA sample consisting of 174 women who specifically identified their ethnicity as Puerto Rican (vs. Hispanic), Himmelgreen et al. (25) reported that BMI was positively associated with acculturation as measured by the number of years in the United States.

As in studies of Mexican American women $(10,11)$, Puerto Rican women in this study were more likely to be obese if they had a low SES as indicated by lower educational level or not owning a car. Furthermore, car ownership had a stronger (positive) association than education or employment with the intake of meat, eggs, and fish. 
Thus, not owning a car might be more clearly associated with a lower SES than lower educational level or unemployment. Women with a very low SES may not be able to afford expensive foods such as meat or fish.

Interestingly, employment was related to a higher likelihood of obesity. Khan et al. (11) detected a similar association among Mexican American women but not among Puerto Rican women. The mechanism of this association may be related with physical activity, since lower levels of physical activity among employed (vs. unemployed) Latinas have been reported by others (36). We did not detect a significant relationship between employment and regular exercise; however, it should be noted that our interview question on physical activity did not ask about occupational or transportation-related activities. Further research is therefore needed to examine how different types of jobs and means of transportation influence nutrition, physical activity, and other lifestyle behaviors.

\section{Physical activity}

Socioeconomic status and physical activity were not significantly related, but SES may be related to activities other than regular exercise, such as transportation-related or occupational activities. We detected a tendency for highly acculturated women to be more physically active, and this is in agreement with previous studies of Mexican American (6) or Latino populations in general (34).

\section{Cigarette smoking}

In the study sample, cigarette smoking was very common (32\%) and more frequent than the national estimates for Mexican American (11\%) or Hispanic women (12\%) (14). Consuming alcohol, being highly acculturated, and not being married were related to cigarette smoking, and these findings are in agreement with previous findings in Mexican American (8) and His- panic populations $(18,37)$. Attributes of Hispanic culture such as greater concern for family members, familismo (20), better social support for smoking cessation (38), or traditional women's role beliefs (37) may underlie the lower smoking rates among less acculturated or married women.

\section{Alcohol intake}

Employment was related to a higher likelihood of alcohol consumption. Other research conducted among Puerto Ricans also indicated a positive association between alcohol intake and SES (7). This association may reflect the ability to afford to purchase alcohol or to attend social events where alcohol is likely to be consumed. Our earlier analyses indicated that social networks were stronger among drinkers vs. nondrinkers (39), and suggested that in our study population, drinking habits might be centered around social interactions.

\section{Food intake patterns}

Although we did not detect a statistically significant association between acculturation and food group intake patterns, other studies of Mexican American (12) and Puerto Rican populations (40) found evidence of such associations, and methodological differences may account for some of the variations between studies. Additionally, acculturation may be related to food intake indirectly through other lifestyle factors. For instance, our analyses showed that cigarette smokers were likely to be highly acculturated and to have a less healthy food intake pattern compared to nonsmokers. Considering the low SES of our study population, limited economic resources might be used to buy cigarettes at the expense of healthy foods. In addition to the health risks of smoking itself, cigarette smokers' less healthy dietary habits may compromise their nutritional and health status even further. This makes it important to consider cultural characteristics in addition to SES and lifestyle behaviors when interventions aimed at modifying food intake patterns are designed.

This study is limited by its crosssectional design, which precludes drawing causal inferences. Although we used a variety of recruitment methods to capture the diversity of the community, this was a convenience sample of low-income inner city Puerto Rican women with young children. Thus, the study results may not be generalizable to other groups. The measurement of physical activity was based on a single question that inquired about usual exercising behaviors; hence, our data may not reflect the participants' overall physical activity.

Since most research involving diabetes and CVD risk factors in Hispanic populations in the United States has been conducted among Mexican Americans, the present needs assessment study provides valuable information that will narrow the existing knowledge gap for low-income Puerto Rican women with young children. As in Mexican American populations, obesity was common in the sample population studied here. Obesity was associated with low SES and high acculturation. Smoking rates were high, and smoking was more common among highly acculturated or unmarried women. There were also associations indicating a lower intake of meat, eggs and fish among those with a low SES, and an unhealthy food intake pattern among smokers. Among Latinas with a low SES or high level of acculturation, there seems to be a need for interventions aimed at obesity prevention, smoking cessation, and nutritional education. In addition to financial limitations that may influence food purchasing decisions, access to and the effective use of nutrition and health information may be limited among low-SES populations. Therefore, culturally appropriate educational interventions should aim to build knowledge and skills that enable individuals to better use their limited resources for a healthier lifestyle. In this process, it is imperative to encour- 
age healthy behaviors from one's primary culture while aiming to prevent unhealthy behaviors that come with higher acculturation (i.e., smoking). Future qualitative research to identify the cultural perceptions, barriers, and motivations for healthy lifestyle behaviors is likely to provide further support for culturally appropriate interventions targeting these behaviors.

Acknowledgments. The authors are thankful to Lisa Phillips at the University of Connecticut for her administrative support, the study participants, and the staff of the Hispanic Health
Council and the Connecticut Hispanic Family Nutrition Program. This work was funded by the USDA Food Stamp Program through a Food Stamp Nutrition Education grant to Rafael PérezEscamilla, and the Connecticut Latino Health Disparities NIH EXPORT Center (grant 1P20MD001765-01).

\section{REFERENCES}

1. Hu F, Manson J, Stampfer M, Colditz G, Liu S, Solomon C, et al. Diet, lifestyle and the risk of type 2 diabetes mellitus in women. $\mathrm{N}$ Eng J Med. 2001;345(11):790-7.

2. Wei M, Gibbons L, Mitchell T, Kampert J, Blair S. Alcohol intake and incidence of type 2 diabetes in men. Diabetes Care. 2000;23(1): 18-22.

3. Hu FB, Stampfer MJ, Manson JE, Grodstein F, Colditz GA, Speizer FE, et al. Trends in the incidence of coronary heart disease and changes in diet and lifestyle in women. $\mathrm{N}$ Engl J Med. 2000;343(8):530-7.

4. Sundquist K, Qvist J, Johansson SE, Sundquist J. The long-term effect of physical activity on incidence of coronary heart disease: A 12-year follow-up study. Prev Med. 2005;41(1):219-25.

5. Tanasescu M, Hu FB, Willett WC, Stampfer MJ, Rimm EB. Alcohol consumption and risk of coronary heart disease among men with type 2 diabetes mellitus. J Am Coll Cardiol. 2001;38(7):1836-42.

6. Crespo C, Smit E, Carter-Pokras O, Andersen $R$. Acculturation and leisure-time physical inactivity in Mexican-American adults: results from NHANES III, 1988-1994. Am J Public Health. 2001;91(8):1254-7.

7. Marks G, Garcia M, Solis JM. Health risk behaviors of Hispanics in the United States: findings from HHANES, 1982-84. Am J Public Health. 1990;80(Suppl):20-6.

8. Haynes SG, Harvey C, Montes H, Nickens H, Cohen BH. Patterns of cigarette smoking among Hispanics in the United States: results from HHANES 1982-84. Am J Public Health. 1990;80(Suppl):47-53.

9. Winkleby MA, Kraemer HC, Ahn DK, Varady AN. Ethnic and socioeconomic differences in cardiovascular disease risk factors. JAMA. 1998;280(4):356-62.

10. Hazuda HP, Mitchell BD, Haffner SM, Stern MP. Obesity in Mexican American subgroups: findings from the San Antonio Heart Study. Am J Clin Nutr. 1991;53(6 Suppl):1529S1534 S.

11. Khan LK, Sobal J, Martorell R. Acculturation, socioeconomic status, and obesity in Mexican Americans, Cuban Americans, and Puerto Ricans. Int J Obes. 1997;21(2):91-6.

12. Dixon LB, Sundquist J, Winkleby M. Differences in energy, nutrient, and food intakes in a US sample of Mexican-American women and men: findings from the Third National Pp. $115-36$
Health and Nutrition Examination Survey, 1988-1994. Am J Epidemiol. 2000;152(6): 548-57.

13. Mazur RE, Marquis GS, Jensen HH. Diet and food insufficiency among Hispanic youths: acculturation and socioeconomic factors in the third National Health and Examination Survey. Am J Clin Nutr. 2003;78(6):1120-7.

14. United States of America, Center for Disease Control and Prevention, CDC National Center for Health Statistics. Health, United States, 2005. Available at: http://www.cdc.gov/ nchs/hus.htm. Accessed 18 April 2006.

15. United States of America, Center for Disease Control and Prevention. Diabetes disabling, deadly, and on the rise. 2005. Available at: www.cdc.gov/diabetes. Accessed 30 June 2005.

16. Flegal K, Ezzati T, Harris M, Haynes S, Juarez RZ, Knowler W, et al. Prevalence of diabetes in Mexican Americans, Cubans, and Puerto Ricans from the Hispanic Health and Nutrition Examination Survey, 1982-1984. Diabetes. 1991;14(7):628-38

17. Perez-Stable EJ, Ramirez A, Villareal R, Talavera $\mathrm{G}$, Trapido E, Suarez L, et al. Cigarette smoking behavior among US Latino men and women from different countries of origin. Am J Public Health. 2001;91(9):1424-30.

18. Crespo CJ, Loria CM, Burt VL. Hypertension and other cardiovascular disease risk factors among Mexican Americans, Cuban Americans, and Puerto Ricans from the Hispanic Health and Nutrition Examination Survey. Public Health Rep. 1996;111(Suppl 2):7-10.

19. Suarez L, Ramirez A. Hispanic/Latino health and disease. In: Huff R, Kline M, eds. Promoting health in multicultural populations. Thousand Oaks: Sage Publications; 1999.

20. Pérez-Escamilla R, Himmelgreen $D$, SeguraMillan S, Gonzalez A, Ferris AM, Damio G et al. Prenatal and perinatal factors associated with breast-feeding initiation among innercity Puerto Rican women. J Am Diet Assoc. 1998;98(6):657-63.

21. DeLeon J. Household composition, acculturation, and diet among low-income Puerto Ricans in Hartford, Connecticut [Ph.D. dissertation]. Tampa (FL): University of Florida; 2000

22. Frisancho A. New standards of weight and body composition by frame size and height for assessment of nutritional status of adults and the elderly. Am J Clin Nutr. 1984;40(4):808-19.
23. United States of America, National Institutes of Health. Clinical guidelines on the identification, evaluation, and treatment of overweight and obesity in adults: National Heart, Lung, and Blood Institute, NIH Publication No. 98-4083; 1998.

24. American College of Sports Medicine. The recommended quantity and quality of exercise for developing and maintaining cardiorespiratory and muscular fitness, and flexibility in healthy adults. Med Sci Sport Exerc. 1998;30(6):975-91.

25. Himmelgreen DA, Perez-Escamilla R, Martinez D, Bretnall A, Eells B, Peng Y, et al. The longer you stay, the bigger you get: length of time and language use in the U.S. are associated with obesity in Puerto Rican women. Am J Phys Anthropol. 2004;125(1): 90-6.

26. Sundquist J, Winkleby M. Country of birth, acculturation status and abdominal obesity in a national sample of Mexican-American women and men. Int J Epidemiol. 2000;29(3): $470-77$.

27. Ebrahim S, Papacosta O, Wannamethee G, Adamson J. Social inequalities and disability in older men: prospective findings from the British regional heart study. Soc Sci Med. 2004; 59(10):2109-20.

28. Gilthorpe MS, Wilson RC. Rural/urban differences in the association between deprivation and healthcare utilisation. Soc Sci Med. 2003;57(11):2055-63.

29. Eachus J, Chan P, Pearson N, Propper C, Davey Smith G. An additional dimension to health inequalities: disease severity and socioeconomic position. J Epidemiol Community Health. 1999;53(10):603-11.

30. Perez-Escamilla R, Ferris AM, Drake L, Haldeman L, Peranick J, Campbell M, et al. Food stamps are associated with food security and dietary intake of inner-city preschoolers from Hartford, Connecticut. J Nutr. 2000; 130(11):2711-7.

31. United States of America, United States Department of Agriculture. Available at: www. mypyramid.gov. Accessed 17 June 2005.

32. Ayala GX, Elder JP, Campbell NR, Slymen DI, Roy N, Engelberg M, et al. Correlates of body mass index and waist-to-hip ratio among Mexican women in the United States: implications for intervention development. Women's Health Issues. 2004;14(5):155-64. 
33. Hubert HB, Snider J, Winkleby MA. Health status, health behaviors, and acculturation factors associated with overweight and obesity in Latinos from a community and agricultural labor camp survey. Prev Med. 2005; 40(6):642-51.

34. Abraído-Lanza AF, Chao MT, Flórez KR. Do healthy behaviors decline with greater acculturation?: Implications for the Latino mortality paradox. Soc Sci Med. 2005;61: 1243-55.

35. Sundquist J, Winkleby MA. Cardiovascular risk factors in Mexican American adults: a transcultural analysis of NHANES III, 19881994. Am J Public Health. 1999;89(5): 723-30.

36. Eyler AA, Matson-Koffman D, Rohm Young D, Wilcox S, Wilbur J, Thompson J, et al.
Quantitative study of correlates of physical activity in women from diverse racial/ethnic groups. The Women's Cardiovascular Health Network Project summary and conclusions. Am J Prev Med. 2003;25(3Si):93-103.

37. Kaplan C, Napoles-Springer A, Stewart S, Perez-Stable EJ. Smoking acquisition among adolescents and young Latinas. The role of socioenvironmental and personal factors. Addictive Behaviors. 2001;26(4):531-50.

38. Serrano VA, Woodruff SI. Smoking-related attitudes and their sociodemographic correlates among Mexican-origin adult smokers. J Community Health. 2003;28(3):209-20.

39. Fitzgerald, N. Identification of risk factors mediating the associations of socioeconomic, cultural, and demographic factors with type 2 diabetes across ethnic groups [PhD Dissertation]. Storrs (CT): University of Connecticut; 2004.

40. Himmelgreen DA, Bretnall A PerezEscamilla R, Peng Y, Bermudez A. Birthplace, length of time in the U.S., and language are associated with diet among inner-city Puerto Rican women. Ecol Food Nutr. 2005;44:105-22.

Manuscript received on 21 October 2005. Revised version accepted for publication on 4 April 2006
RESUMEN

\section{Aculturación, clase social, obesidad y factores relacionados con el estilo de vida en mujeres puertorriqueñas de bajos ingresos residentes del estado de Connecticut, Estados Unidos, 1998-1999}

Palabras clave
Objetivos. Examinar las asociaciones entre el estado socioeconómico y la aculturación con las características del estilo de vida que podrían constituir factores de riesgo de diabetes y de enfermedades cardiovasculares en mujeres puertorriqueñas de bajos ingresos.

Métodos. Este estudio transversal se llevó a cabo entre 1998 y 1999 mediante entrevistas a una muestra de conveniencia compuesta de 200 mujeres puertorriqueñas de bajos ingresos que cuidaban a niños pequeños en Hartford, Connecticut, Estados Unidos de América. Se usaron diversas formas de reclutamiento para conseguir que hubiera una buena representación de la comunidad blanco. Las asociaciones entre la obesidad (índice de masa corporal $>30,0$ ) y factores propios del estilo de vida (actividad física, tabaquismo, consumo de alcohol, alimentación) por un lado y la clase social (escolaridad, empleo, tenencia de un automóvil), aculturación, edad y estado civil por el otro se examinaron mediante la prueba de rho de Spearman, la de ji al cuadrado y la de la $U$ de Mann-Whitney y análisis de regresión logística.

Resultados. La edad promedio fue de 29 años. La obesidad (40\%), inactividad física $(47 \%)$ y el tabaquismo (32\%) fueron comunes. Las participantes con menos grado de aculturación fueron $57 \%$ menos propensas a ser fumadoras y $54 \%$ menos propensas a ser obesas que las que estaban más aculturadas. Pertenecer a una clase social más baja (no haber terminado la secundaria o no tener automóvil) se asoció con una mayor probabilidad de ser obesa, pero las mujeres sin trabajo (por oposición a las que sí lo tenían) mostraron menor propensión a ser obesas $(P<0,05)$. Las mujeres que no tenían automóvil consumían carne, huevos y pescado con menos frecuencia que las que sí lo tenían. Las fumadoras tenían más probabilidad de tener una alimentación malsana que las que no fumaban.

Conclusiones. Las asociaciones entre el grado de aculturación y el estado socioeconómico con algunas características del estilo de vida apuntan a la necesidad de crear programas apropiados desde el punto de vista cultural para promover conductas sanas en esta comunidad de bajos ingresos.

Aculturación; enfermedades cardiovasculares, diabetes, hispanoamericanos, obesidad, actividad física, clase social, mujeres, Puerto Rico. 